\title{
The EU in 2030: An Anticipated Look Back at the 2020s
}

Franz C. Mayer*

\section{A. Introduction}

Lawyers are not particularly well suited to reflect on the future. They typically deal with political compromises of the past, transformed into the law of today. As textualists, lawyers are genetically programmed to primarily look back and defend the existing ${ }^{1}$ Nevertheless, I still want to give EU legal futurology a try, as reflection on possible future developments can be helpful to better understand current developments in European integration and the challenges it faces today.

\section{B. Methodology}

Legal science fiction or legal futurology has not (yet) emerged as a new discipline. Yet, the question of how a specific field of law may develop in the future can be asked about any field of law. The peculiar difficulty with EU law is that it is not only about future developments of case law or of a doctrinal concept. It is closely linked with the future of the European polity and the political project of European integration. Thus, there is a twofold question here: On the future of EU law and on the future of the EU.

There are at least two approaches to generate some insight about the EU in 2030. One method is projection based on the previous development of the EU and the current status quo. The other approach consists of developing scenarios for the future.

\section{Projections and Scenarios}

Projection is simple when it looks at what has remained unaltered over time. When an idea has remained constant over time, then you simply prolong lines into the future. In contrast, dynamic processes are more difficult to capture, but one can still try to detect trends and tendencies that point towards a certain direction, and then reflect on the probability of this trend persisting in the future. Conventional wisdom holds that for EU law, this kind of analysis is easy. With the "ever closer union" inscribed into the treaties, everything in EU law seems to point to ever more integration. The reality, however, is more complicated. While it is true that powers and competences of the European level have increased since 1957, the new EU powers that came with the Treaty of Lisbon are quite limited.

${ }^{\star}$ Prof. Dr. jur., LL.M. (Yale), Chair of Public Law, European Law, Public International Law, Comparative Law and Legal Policy, Faculty of Law, University of Bielefeld. This article builds on earlier presentations on European legal futurology, parts of it were presented at a joint hearing of the EU affairs committees of the Bundestag and the Bundesrat in November 2019. I wish to thank Simon Thies (Bielefeld/Cambridge) for his invaluable research assistance.

${ }^{1}$ Beyond textualism, legal science in general is still revolving around concepts that are centuries old. Imagine medicine or natural science being stuck with theoretical concepts and tools of the 19th century-and older-the way lawyers are. One may wonder to what extent ancient concepts such as sovereignty or federalism can prove helpful in the 21 st century in a world that has experienced fundamental changes over the last 200 years. 
The transfer of huge areas of competences has actually come to a halt with the Maastricht Treaty in 1992. On the other hand, there are numerous foundational elements of EU law that have remained stable, making it likely that these elements will remain in place even in the more distant future. The direct effect and primacy of EU law are probably the most prominent examples. Equally important is the fact that the law of fundamental freedoms establishing the single market has remained unaltered in its core principles over the years. The EU 27 have defended this part of EU law vigorously during the Brexit process. It therefore appears quite probable that this part of EU law will remain stable over the next ten or twenty years as well. ${ }^{2}$

The alternative approach is to generate insight on future developments: Scenarios. This has been tried in the past. Let me point out two examples: ${ }^{3}$ A study of the planning unit of the European Commission from $1999 ;^{4}$ and a joint study of the policy planning units of the German and French ministries of foreign affairs from $2000 .^{5}$ If there is one thing these two examples illustrate, it is that the future is uncertain.

None of the studies anticipated the Euro crisis. What could be future issues or developments of a magnitude similar to the Euro crisis that could potentially affect the governance arrangements in Europe in an equally fundamental and transformative way?

Arguably, it may be sufficient to quote from the latest headlines: Climate change and migration towards and within Europe. Other issues could be cross-border health risks related to infectious disease outbreaks; energy supply shortages in Europe; rulers who think in territorial categories of the 19th century, inside the EU (Orban) or outside (Putin, Trump); ${ }^{6}$ China's role in a changing world. And there is technological change with the emergence of a digital society. ${ }^{7}$ The multiplicity of these issues explains the limits of detailed scenarios on the future. In particular with a view to developments that we cannot anticipate today. We must note, however, that there is something common to most of my examples that is also a hallmark of the Euro and the refugee crisis: The reach of the problem goes well beyond the available problem-solving capacity of the nation state.

The opposite of detailed scenarios are very general — arguably oversimplified — scenarios. Let me point out three of them. First, there is a scenario of more integration. I will call that the federal state scenario, or the United States of Europe scenario. Then, there is a scenario of less integration, with the EU winding down towards a qualified free trade arrangement or less. Finally, there is a scenario of maintaining the status quo. There are indicators for all three developments.

\footnotetext{
${ }^{2}$ The projection approach could also be applied to the institutional setting. An analysis here would have to assess the significance for the future direction of the EU of past developments, such as the increasing power of the European Council and the rise of intergovernmentalism in the Euro crisis; the ambiguous role of the Commission between guardian of the European common good and brutal promoter of institutional self-interest over the past years; the rise of an independent player such as the ECB; the shrinking democracy enhancing potential of a European Parliament because of exogenousturn-out, election results, stature of elected personnel - and endogenous, self-inflicted factors - the Goulard affair as an example for an EP legitimacy overstretch; and the challenges to the authority of the ECJ by courts of the Member States.

${ }^{3}$ I will not address the most recent comprehensive effort by the European Commission: White Paper on the Future of Europe: Five Scenarios, as it was explicitly meant to cover the time span until 2025 only. See White Paper on the Future of Europe, at 15-24 (Mar. 1, 2017), https://ec.europa.eu/commission/sites/beta-political/files/white_paper_on_the_future_of_europe_en.pdf.

${ }^{4}$ The planning unit was the "Forward Studies Unit" then. Five scenarios for the future development of Europe until 2010 were presented in 137 pages. See European Commission Forward Studies Unit, Five Possible Futures for Europe (1999), http:// europa.eu.int/comm/cdp/mission/index_en.htm.

${ }^{5}$ Auswärtiges Amt Planungsstab \& Ministère des Affaires Étrangères Centre d'Analyse et de Prévision on the "Ein Europa mit dreißig und mehr Mitgliedern. L'Europe a trente Etats membres et plus," (2000) (“A Europe with 30 and more Member States"), on file with the author.

${ }^{6}$ Arguably, Turkey under the rule of President Erdogan also falls into this category.

${ }^{7}$ See Dave Eggers, The Circle (Alfred A. Knopf, 2013) (illustrating what a future where private information services providers, and not the state, rule could look like. Even more unsettling are predictions on the darker aspects of AI, or artificial intelligence).
} 
The federal state scenario is plausible because of general futurological observations. It is a frequent scenario used in popular culture. For example, just consider the Star Trek TV series and movies, situated in the 22nd and the 24th centuries. There, political power is organized in the form of a "United Federation of Planets," an interstellar polity of planetary governments. This is just one out of many examples in literature and film foreseeing future political arrangements as allembracing federations. Obviously, it is easy to criticize this as the expression of an Americacentered popular culture, and it is true that American authors of these kinds of future scenarios appear to have modeled the future simply along the lines of the history of the USA. Nevertheless, isn't it also true that history teaches us that typically loose political arrangements, over time, morph into something more solid, from confederation to federation, from Staatenbund to Bundesstaat: Switzerland, the USA, and Germany are examples in that context. Some political parties in Germany still have the United States of Europe in their party programs. ${ }^{8}$ There would be much to say on this. As I reflect on 2030 and not 2130 or 2330, I will get to the core objection immediately: In order to form a federation, it is not sufficient to have only Germany heading for this aim. You would need others to join in. ${ }^{9}$ That is not in sight.

Compared to this, currently the disintegration scenario appears more likely. Looking back in 2030, people will probably say the following:

European integration was a unique idea that could only become reality within a small window of opportunity immediately after World War II, while the failure of the nation state and the horrors of war were still omnipresent. With this memory fading away, the entire integration project became increasingly implausible, slowly winding down. After the reunification, Germany became increasingly self-centered, less and less capable to adopt other countries perspective, with Germans still seeing themselves as 'good Europeans'. Meanwhile, Germany had reached a pre-dominance, maybe even a hegemony in Europe in economic and political terms. European integration was - seemingly - no longer needed in order to push through German interests. The German Constitutional Court accompanied and assisted this development with its sovereignty-centered jurisprudence as of the beginning of the 1990s.

Evidence for this scenario is hard to deny. Today, European integration is on the defensive. This is the case not only because of Brexit. Proponents of more European integration are going through a difficult time almost everywhere in Europe. Nationalist populists are on the rise in many countries, not only in Europe. ${ }^{10}$

This observation seems to be at odds with observations made earlier: Future problems will require even more overarching collaboration; the mechanisms of EU law point to sustained and deepened integration; also, the core of EU law is still stable, with its stability seemingly increasing. All things considered, all this may lead to finding ourselves in more or less the same degree of integration as today in ten or twenty years. There will neither be the United States of Europe just around the corner, nor decay towards some kind of a free trade area. Instead, we may find ourselves with the status quo.

The twist here could be that, in order to maintain the status quo, further steps of integration may be necessary. There is some evidence that the size of the Union and the current decisionmaking process are the key topics. The number of Member States has increased continuously

\footnotetext{
${ }^{8}$ See Sozialdemokratischen Partei Deutschlands, Hamburger Programm. Grundsatzprogramm der Sozialdemokratischen Partei Deutschlands vom 12 (2007); Freie Demokratische Partei, Verantwortung für die Freiheit. Karlsruher Freiheitsthesen der FDP FÜr EINE OFFEne BÜrgergesellschaft vom 95 (2012).

${ }^{9}$ See Luuk van Middelaar, The Passage to Europe: How a Continent Became a Union 226 (Yale Univ. Press, 2013) (showing a slightly different context).

${ }^{10}$ The rise of the irrational is not limited to Europe. It constitutes a particular threat to law. After all, the idea of law itself, of the rule of law and of an international legal order require rationality and relay on a rational, long term assessment of interests.
} 
in the past, and it is quite probable that it will further increase until 2030. Departures are also a possibility as Brexit illustrates. But there are also candidates for accession. ${ }^{11}$ It seems fair to say that the number and diversity of Member states will not decline significantly, and that is a problem. One of the more reliable trends of the recent past was that enlargement of the Union went hand in hand with increasing difficulties within the decision-making process in the European institutions. This is the case whenever unanimity is required, but also beyond unanimity. Already, the communicative setting of debates and negotiations is totally different today compared to 1957, with twenty-eight or more players involved. A mere tour de table to get an array of opinions can take hours, not to mention the increasingly diverse interests. This is an institutional problem that is not always easy to grasp, because the catastrophic breakdown of the system with a big bang has not happened, ${ }^{12}$ rather it whimpers here and there. The perception is that the EU decision-making process is in descent, but even a slow descent comes to a landing at some point. ${ }^{13}$ Status quo without reform effort is not sufficient.

To assess what is at stake here, I have to turn to the deeper explanation and justification of European integration. It may be easier to explain in the current political circumstances than just a couple of years ago: There is the idea that either Donald Trump or Vladimir Putin or both should be given the Charlemagne Prize as a tribute for fostering European integration and enhancing European cohesion at some point in the future. The Ukraine crisis with the annexation of the Crimea by Russia crossed a line as it constituted the first unilateral modification of territorial boundaries between states by force in Europe since 1945. This recalls what the core of the European integration is all about: A project to establish and maintain peace in Europe, internally and externally.

The following idea is far from being outdated: European integration is the lesson drawn from three devastating wars between France and Germany within the time span of 70 years, with two world wars resulting in a devastated Europe, mourning more than 55 million dead. Diverging interests between states still exist. The way conflicts and disputes are settled today, however, is that we lock our heads of state and government away into negotiation rooms, until they have found a consensus; that we have a European Commission that brings states to a supranational Court of Justice in Luxemburg in order to sort things out. This is an incredible leap of civilization, with law as a core element. In a community of law, law prevails over force. ${ }^{14}$ To maintain this acquired degree of civilization and civility, this is what it is all about. We will not succeed to maintain this achievement without any reform effort. But there is also a narrative side to it: The narrative needs to be explained, upheld and passed from generation to generation. ${ }^{15}$ It is quite easy to simply declare that all this stems from the past and is of no more interest today, but consider the U.S. Declaration of Independence from 1776, or the storming of the Bastille in France in 1789. It is not necessary to have lived an event to consider it part of a collective

\footnotetext{
${ }^{11}$ Currently, Albania, the Republic of North Macedonia, Montenegro, Serbia, and Turkey are official candidate countries. Turkey has been a candidate for many years now; although, more recent developments make it increasingly unthinkable that Turkey will ever join the European Union. Maybe in the more distant future, Ukraine, Norway, and Switzerland could become candidates - again. It is uncertain that all forty-seven of the current member states of the Council of Europe will join the EU.

${ }^{12}$ E.g., Steven Levitsky \& Daniel Ziblatt, How Democracies Die: What History Reveals About Our Future (2018) (illustrating examples of a different kind of erosion of decision-making).

${ }^{13}$ See Ivan Krastev, After Europe (Univ. of Penn. Press, 2017) (illustrating the analysis in that context). See also IvaN KrasteV, EUROPADÄMMERUNG (Suhrkamp Verlag; Deutsche Erstausgabe ed., 2017) (illustrating an even more fitting example in the German title that translates to "the dusk of Europe").

${ }^{14}$ In the European integration context, this idea of a "community of law" (Rechtsgemeinschaft) is closely linked with Walter Hallstein. See Franz C. Mayer, Die Europäische Union als Rechtsgemeinschaft, 2017 Neue JuristisCHE WOCHENSCHRIFT 3631.

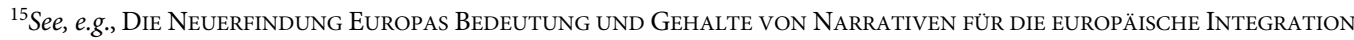
(Claudio Franzius et al. eds., 2019).
} 
memory. ${ }^{16}$ What would be wrong with a European pathos insisting on an understanding of European integration primarily as a lasting project of peace, a guarantee of our way —or ways - of peaceful life in Europe? Emmanuel Macron has proven that one can even win elections with that stance.

\section{The Near Future and Next Steps to Take}

There are at least four aspects that may be relevant in order to make European integration more future-proof:

1) One of the core problems of European constitutional law and its evolution is that a modification of the Treaties requires a unanimous decision as well as ratification in all Member States. This double unanimity is so hard to reach nowadays that any suggestion of a quick improvement of the treaty foundations of European integration is considered a non-starter and just does not happen. ${ }^{17}$

2) The monetary union should remain the focal point of any reform, with a view to a EuroUnion among the states that have accepted the Euro as their common currency. The inherent logic here is that the currency remains one of the traditional markers of sovereignty; and taking the - sovereign-decision to freely pool this aspect of sovereignty with others leads to a mutual dependency on each other that makes a deeper degree of integration inevitable. This is also about perpetuating the lessons learned from the existential experience gone through within the Euro zone during the Euro crisis of being inescapably bound together in this crisis. Decision-making by majority should be the default rule here. The recent reform efforts do not appear to be sufficient. ${ }^{18}$

3) Initiating a fresh reform process will only be successful if the initial steps remain extremely modest. Reforming the protocol of the Euro group could be such a modest beginning. We will see whether the "Conference on the future of Europe", initially suggested by French President Macron, then endorsed by the new President of the European Commission Von der Leyen, and subject of a Franco-German non-paper, ${ }^{19}$ will manage to focus on modest steps. In recent years, it was lack of political will of the Member States and not the insufficient legal-institutional frame work that appeared as the major problem. No conference should obscure this.

4) Finally, from a German perspective, one has to constantly keep the imperatives of German constitutional law in mind. This goes well beyond the present contribution. Suffice it to say that the Basic Law from 1949 is initially a constitution that is open for European integration. It contains a constitutional aim, Staatsziel (United Europe), which all public authorities are called upon to pursue. ${ }^{20} \mathrm{~A}$ firm entrenchment of Germany in an integrated Europe

\footnotetext{
${ }^{16}$ The 14th of July became a national holiday in France only 100 years after the actual downfall of the Bastille in 1880 .

${ }^{17}$ This is part of the explanation why treaty-level solutions in the context of the Euro crisis were established on side tracks and not within the TFEU or the TEU.

${ }^{18}$ See Federal Ministry of Finance, French German Roadmap for the Euro Area, MESEBERG DeClaration (June 20, 2018), https://www.bundesfinanzministerium.de/Content/EN/Standardartikel/Topics/Europe/Articles/2018-06-20-Meseberg-att1. pdf (illustrating the current state of affairs of Franco-Germany).

${ }^{19} \mathrm{See}$ https://www.politico.eu/wp-content/uploads/2019/11/Conference-on-the-Future-of-Europe.pdf ("Conference on the Future of Europe. Franco-German non-paper on key questions and guidelines”, November 2019), Rym Momtaz and David M. Herszenhorn, Berlin and Paris outline plan for EU makeover, https://www.politico.eu/article/berlin-and-paris-outline-planfor-eu-makeover/.

${ }^{20}$ See GRUNDGESETZ [GG] [BASIC LAw], translation at https://www.gesetze-im-internet.de/englisch_gg/ (looking specifically at the Preamble and Article 23).
} 
was actually one of the preconditions for giving full sovereignty back to Germany. ${ }^{21}$ What is really necessary here is a look in the mirror concerning the role and position of Germany in Europe as well as a sober assessment of Germany's best interest, which is to keep German interests in sync with European interests.

\section{E. Conclusion}

I confess that I have not really revealed what the EU will look like in 2030 and probably did not boldly go where no lawyer has gone before. Instead, I tried to anticipate future developments of EU law and the EU based on current trends. This led me to the assessment that it may be less a matter of genuinely more integration, but rather a matter of upholding what we have already accomplished.

One final thought on the lesson we can learn from Brexit, the Euro/sovereign debt crisis that began in Greece or the rule of law crisis that emerged in Poland and Hungary, spilling over to other countries: What the EU will look like in in 2030, both politically and constitutionally, depends decisively on the respective developments in the 27 or more Member States, which is way beyond the scope of this article. For the countries I know best, Germany and France, I would not be able to predict the political landscape in 2030. As far as German constitutional law is concerned, I would welcome a number of clarifications in order to confirm that the constitutional aim of "United Europe" is still to be taken seriously. In the words of Thomas Mann:22 a European Germany, not a German Europe as leitmotiv - also in the context of constitutional adjudication by the German Constitutional Court. ${ }^{23}$ It is the risk and the asset of engaging in legal futurology that all predictions on possible future developments can be verified-we will have to wait for 2030 though.

\footnotetext{
${ }^{21}$ See Convention on Relations between the Three Powers and the Federal Republic of Germany, France, the United States, the United Kingdom, Germany, art. 7, Oct. 23, 1954, 6 UST 4251, 331 UNTS 327-366.

${ }^{22}$ Thomas Mann, das nebelhorn. Eine Zeitung Hamburger Studenten, 1 ANSPRACHE vor Hamburger Studenten, June 12, 1953 at. 1 (addressing students in Hamburg in 1953 and encouraging them to declare their support: "nicht zu einem deutschen Europa, sondern zu einem europäischen Deutschland” [not for a German Europe, but for a European Germany]).

${ }^{23}$ The decisions of the German Constitutional Court from November 2019 on fundamental rights protection and the EU where the court announces that from now on it will use the EU Fundamental Rights Charter as a yardstick in its own decisions may be developed in either direction, towards Europeanizing the German fundamental rights order or towards Germanizing European fundamental rights, see Decisions 1 BvR 276/17 and 1 BvR 16/13, 6 November 2019 ("Recht auf Vergessen werden" I and II).
} 